\title{
Sequential post-heading applications for controlling wheat blast: a summary of fungicide performance
}

João P. Ascari ${ }^{1 \dagger}$, Jhonatan P. Barro' ${ }^{1 \dagger}$, Flávio M. Santana², José M.V. Padua ${ }^{3}$, João L. N. Maciel², Douglas Lau $^{2}$, Gisele A. M. Torres ${ }^{2}$, Cheila C. Sbalcheiro ${ }^{2}$, Claudine D. S. Seixas ${ }^{4}$, Augusto C. P. Goulart ${ }^{5}$, Angelo A. B. Sussel ${ }^{6}$, Carlos A. Schipanski ${ }^{7}$, Débora F. Chagas ${ }^{7}$, Maurício A. O. Coelho ${ }^{8}$, Tatiane D. N. Montecelli $^{9}$, Daniel R. Amaral ${ }^{10}$, Adriano A. P. Custódio ${ }^{11}$, Lucas S. O. Moreira ${ }^{11}$, Carlos M. Utiamada ${ }^{12}$, Wilson S. Venâncio ${ }^{13}$, Rita C. S. Goussain ${ }^{14}$, Kaique S. Alves ${ }^{1}$, Emerson M. Del Ponte ${ }^{1 *}$

Wheat blast, caused by Pyricularia oryzae Triticum (PoT) lineage, is a major constraint to wheat production, mainly in the tropics of Brazil where severe epidemics are more frequent. We analyzed disease and wheat yield data from 42 uniform field trials conducted during nine years (2012 to 2020) in order to assess whether the percent control and yield response were influenced by fungicide type, region (tropical or subtropical), and year. Six treatments were selected, all evaluated in at least 19 trials. Two fungicides were applied as solo active ingredients: MANCozeb, and TEBUconazole, and four were premixes: AZOXistrobin + TEBU, TriFLoXistrobin + PROThioconazole, TFLX + TEBU, and PYRAclostrobin + EPOXiconazole. Percent control, calculated from back-transforming estimates by a meta-analysis network model fitted to the log of the means, ranged from $43 \%$ to $58 \%$, with all but PYRA + EPOX showing efficacy greater than $52 \%$ on average, not differing among them. The variation in both efficacy and yield response were explained by region and all but TEBU performed better in the subtropics than in the tropics. Yield response from using three sequential sprays was around two times greater in the subtropics ( 319 to $532 \mathrm{~kg} / \mathrm{ha}$ ) than in the tropics (149 to 241.3 $\mathrm{kg} / \mathrm{ha}$ ). No significant decline in fungicide efficacy or yield response were observed in nine years of study for any of the fungicides. Our results reinforce the need to improve control by adopting an integrated management approach in the tropics given the poorer performance and lower profitability, especially for the premixes, than in the subtropics.

Pyricularia oryzae | chemical control | profitability | meta-analysis

\footnotetext{
${ }^{1}$ Departamento de Fitopatologia, Universidade Federal de Viçosa, 36570-000, Viçosa, MG, Brazil

${ }^{2}$ Embrapa Trigo, 99050-970, Passo Fundo, RS, Brazil

${ }^{3}$ Departamento de Agricultura, Universidade Federal de Lavras, Lavras, MG, Brazil

${ }^{4}$ Embrapa Soja, 86001-970, Londrina, PR, Brazil

${ }^{5}$ Embrapa Agropecuária Oeste, 79804-970, Dourados, MS, Brazil

${ }^{6}$ Embrapa Cerrados, 73310-970, Planaltina, DF, Brazil

${ }^{7}$ G12 Agro Pesquisa e Consultoria Agronômica, 85015-344, Guarapuava, PR, Brazil

${ }^{8}$ Empresa de Pesquisa Agropecuária de Minas Gerais, 38001-970, Uberaba, MG, Brazil

${ }^{9}$ Coodetec, 85818-650, Cascavel, PR, Brazil

${ }^{10}$ Instituto Federal do Triângulo Mineiro 38064-790, Uberaba, MG, Brazil

${ }^{11}$ Instituto de Desenvolvimento Rural do Paraná, 86047-902, Londrina, PR, Brazil

12 Tagro, 86.070-460, Londrina, PR, Brazil

${ }^{13}$ Estação Experimental Agrícola Campos Gerais, 84130-000, Palmeira, PR, Brazil

${ }^{14}$ Instituto Federal do Mato Grosso, 78840-000, Campo Verde, MT, Brazil
}

$\dagger$ These authors contributed equally

*Corresponding author: delponte@ufv.br 


\section{Introduction}

Wheat blast is caused by Pyricularia oryzae Triticum lineage (PoT, syn Magnaporthe oryzae, MoT), an ascomycete fungus first found in 1985 in the state of Paraná, Brazil (Igarashi et al. 1986). Since then, PoT has spread to other wheat-growing countries in South America, including Bolivia, Paraguay, Argentina, and Uruguay (Cruz and Valent 2017; Ceresini et al. 2018). About thirty years after its discovery, the global concern with wheat blast epidemics increased significantly after its report in South Asia (Malaker et al. 2016), and East Africa (Zambia) (Tembo et al. 2020).

The fungus infects both the leaves and the heads of the wheat plant, but infections that occur during the reproductive stage are more frequent and of major economic significance; complete bleaching of heads may occur that severely affects grain filling (Cruz and Valent 2017; Ceresini et al. 2018). Foliar infections are generally mild in wheat but may increase in severity and importance for head infections when warm and wet weather prevails during the early season (Cruz et al. 2016; Perelló et al. 2017). An early yield loss study reported a $27 \%$ reduction in yield due to wheat blast (Goulart et al. 1990), but up to $70 \%$ of the yield can be reduced depending on the infection timing, weather conditions, and cultivar susceptibility (Goulart and Paiva 2000).

Although the disease is present in a wide range of latitude, the most severe epidemics have been reported in wheat-growing regions in the tropics, during the summer/fall season plantings, such as those in Central Brazil and Bolívia (Pagani et al. 2014), and more recently, in Bangladesh (Islam et al. 2019). Once PoT is introduced, the necrotrophic fungus is capable of infecting and surviving in other grasses nearby wheat fields which are assumed to serve as a source of inoculum for epidemics in wheat if they are present prior to the wheat season (Tosa and Chuma 2014; Urashima et al. 2017; Ceresini et al. 2019). The ability of the fungus to disperse long distances is not entirely known but evidence has shown that Pyricularia spores can disperse through air currents up to $1 \mathrm{~km}$ distant from the source (Urashima et al. 2007), or across continents via infected seeds (Ceresini et al. 2018). Although several control methods have been explored in research, including biological control agents (Chakraborty et al. 2020a, 2020b), the combination of cultural (Coelho et al. 2016), genetic, and chemical control have been commercially feasible and more effective in disease management (Cruz et al. 2019; Cruppe et al. 2020).

Several chemicals have been evaluated for the control of the disease since the first blast epidemics at the hotspot regions in Brazil (Goulart and Paiva 1993).
Research in the country has shown that two to three sequential applications of fungicides may be required for disease control, yet with relatively modest levels of control being achieved (Santana et al. 2013). Currently, fifty-three commercial fungicides have been registered for wheat blast control in Brazil (AGROFIT 2021). These include quinone outside inhibitor (QoI) and demethylation inhibitor (DMI) marketed solely or mixed together, but also multi-site mode of action fungicides such as mancozeb.

Despite the importance of wheat blast, the number of publications on chemical control of wheat blast is relatively small and the results are inconsistent. Successful control with efficacy as high as $90 \%$ has been achieved when combining the use of QoI + DMI premix and less susceptible cultivar (Rios et al. 2016). However, levels as low as $45 \%$ efficacy have been reported in susceptible cultivars grown at very favorable environments for blast outbreaks in the Brazilian Cerrado (Pagani et al. 2014). In Bangladesh, 19commercial fungicides had their efficacy tested on a susceptible cultivar, and the blast control levels ranged from $43 \%$ to $96 \%$ (Roy et al. 2020). A 23-environment fungicide trial conducted in Brazil and Bolivia reported various levels of efficacy for QoI, DMI, and multi-site fungicides depending on disease pressure (Cruz et al. 2019).

Meta-analytic approaches have become standard to summarize the effect of treatments for fungicide testing data, including wheat diseases (Paul et al. 2008, 2018a; Machado et al. 2017; Barro et al. 2019, 2020). Uniform fungicide trials targeting wheat blast control were established in 2011 and performed yearly following a standardized protocol. The main goal of the network is to gather information on disease control and yield loss prevention across the main growing regions. The results have been published as technical reports (Santana et al., 2014; 2016a; 2016b; 2019a; 2019b; 2020a; 2020b).

Our objectives were to: 1) obtain meta-analytic estimates of WB control efficacy and yield response; 2 ) evaluate whether the estimates vary over time, space, and on different levels of disease or yield; and 3) calculate fungicide profitability based on the breakeven probabilities.

\section{Material and Methods}

\section{Data source}

Data were obtained from 44 field trials conducted by researchers of the wheat blast cooperative fungicide trial network (Rede de Ensaios Cooperativos de Brusone do Trigo) during nine years (seasons) (2012-2020). The 
data have been published primarily in yearly single reports for ranking fungicide efficacy (Santana et al. 2014, 2013, 2016b, 2016c, 2016a, 2019b, 2019a, 2020a, 2020b). Data from the 2020 season has not been published.

The trials were conducted in eleven municipalities across six Brazilian States: Paraná (PR), São Paulo (SP), Distrito Federal (DF), Mato Grosso (MT), Mato Grosso do Sul (MS), and Minas Gerais (MG) (Fig. 1). The trials were grouped into two climatic regions: Tropical (19 trials [DF, MT, MS, MG]) and Subtropical (25 trials [PR, SP]).

\section{Wheat blast and grain yield assessments}

Head blast incidence (INC) (proportion of diseased head) and conditional severity (SEV) (proportion of diseased spikelets in the diseased head) (Maciel et al. 2013) were visually assessed in $2 \mathrm{~m}$-lines at wheat grain soft dough stage (85 of Zadoks growth stages) (Zadoks et al. 1974). Wheat blast index was calculated as WBI = $(\mathrm{INC} * \mathrm{SEV}) / 100$. At least $5 \mathrm{~m}^{2}$-plants were harvested at full maturity. Grain weight and moisture were obtained for each treatment plot (fungicide + untreated). Crop yield was expressed in $\mathrm{kg} / \mathrm{ha}$ at $13 \%$ moisture.

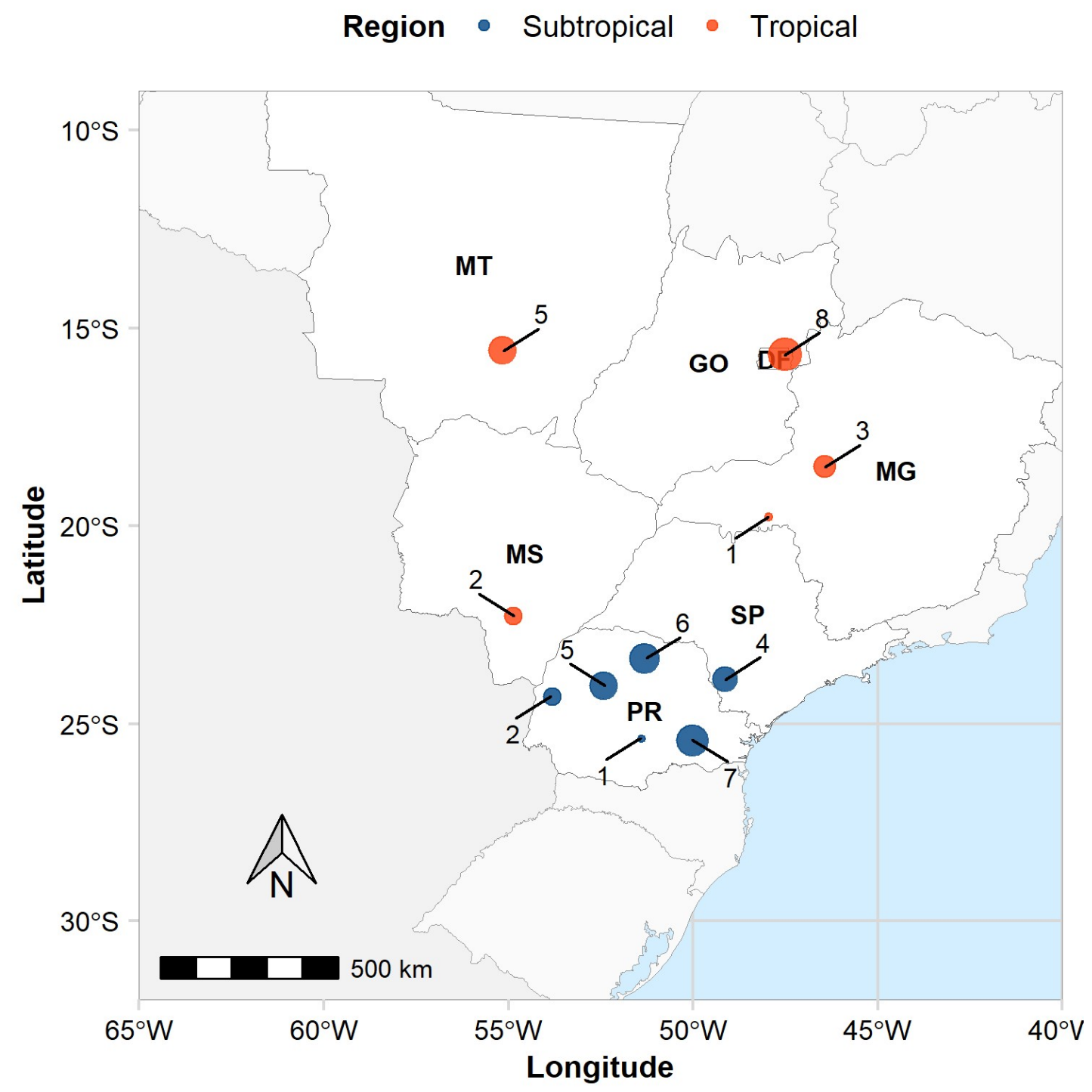

Fig. 1. Geolocation of eleven municipalities across six Brazilian states where 44 fungicide trials were conducted from 2012 to 2020 (Campo Mourão - PR, Guarapuava - PR, Campo Verde - MT, Dourados - MS, Itaberá - SP, Londrina - PR, Palmeira - PR, Palotina - PR, Patos de Minas - MG, Planaltina - DF, Uberaba - MG). Dots were colored by climatic region and the size of the circle is proportional to the number of trials conducted at each location. 


\section{Fungicide treatment selection}

To be included in the analysis, a fungicide treatment should have been tested in at least 19 trials conducted in at least four years and compared with an untreated check in the same trial. Six fungicides met the criteria, including four DMI + QoI premixes, and two single active ingredients (Table 1). After treatment selection, WBI and grain yield data were available in 42 trials each.

\section{Network meta-analysis and inconsistency}

The data were available at the plot level for all treatments for each variable of interest (WBI and grain yield). These were aggregated at the trial level, which is a typical approach used in the meta-analysis (Madden et al. 2016). We fitted an arm-based network model, also known as a two-way unconditional linear mixed model, directly to the treatment means (log-transformed or untransformed) to further obtain control efficacy and yield response (Paul et al. 2008; Machado et al. 2017). Given the statistical properties of the data (Fig. S1), means of WBI were log-transformed, while no transformation was required to obtain the mean difference in yield. The arm-based model can be written as

$$
Y_{i} \sim N\left(\mu, \Sigma+S_{i}\right)
$$

where $Y_{i}$ is the vector of $L$ ( $\log$ of the means of WBI) or absolute yield (D) for the six treatments plus the untreated check for the ith study, $\mu$ is a vector representing the mean of $Y_{i}$ across all studies, $\Sigma$ is a $7 \mathrm{x}$ 7 between-study variance-covariance matrix (for the six treatments plus the untreated check), and $S_{i}$ is a within-study variance-covariance matrix for the $i$ th study. Nindicates a multivariate normal distribution.

For this approach, a measure of within-study variability is required to weight studies based on the inverse function of the sampling variance (Paul et al. 2008, 2010). Given the availability of data at the plot level, the within-study variability of $L$ and $D$ was calculated from the mean square error (MSE) obtained from a linear mixed model fitted to each individual trial, as described (Machado et al. 2017). Maximum likelihood estimation models were fitted to the data using the rma.mv function of metafor package (Viechtbauer 2010) of $\mathrm{R}$ ( $\mathrm{R}$ Core Team 2021).

Table 1. Fungicide treatments evaluated for controlling wheat blast in 44 independent field trials conducted across six Brazilian states (PR, SP, DF, MT, MS, and MG) from 2012 to 2020.

\begin{tabular}{lllccc}
\hline Fungicide a.i. & $\begin{array}{l}\text { Chemical } \\
\text { group }^{\mathrm{b}}\end{array}$ & Brand name & $\begin{array}{c}\mathrm{N}^{\mathrm{o}} \\
\text { trials }\end{array}$ & $\begin{array}{c}\text { Dosage } \\
\left(\mathrm{mL} / \mathrm{g} \mathrm{ha}^{-1}\right)\end{array}$ & $\begin{array}{c}\text { Cost }^{\mathrm{d}} \\
\left(\mathrm{USS} / \mathrm{ha}^{\mathrm{a}}\right)\end{array}$ \\
\hline AZOX+TEBU & QoI+DMI & Azimut & 28 & 750 & 73 \\
MANC & DTC & Unizeb Gold & 41 & 3,000 & 50 \\
PYRA+EPOX & QoI+DMI & Opera & 28 & 500 & 45 \\
TEBU & DMI & Tebuco Nortox & 19 & 500 & 52 \\
TFLX+PROT & QoI+DMI & Fox & 44 & 500 & 82 \\
TFLX+TEBU & QoI+DMI & Nativo & 44 & 750 & 75
\end{tabular}

\footnotetext{
a a.i. (active ingredient); AZOX + TEBU = azoxystrobin + tebuconazole; MANC = mancozeb; PYRA + EPOX = pyraclostrobin + epoxiconazole; TEBU

$=$ tebuconazole TFLX + PROT = trifloxystrobin + prothioconazole TFLX + TEBU = trifloxystrobin + tebuconazole.

${ }^{\mathrm{b}}$ QoI = Quinone-outside inhibitors; DMI = Sterol demethylation inhibitor; DTC = Dithiocarbamate.

c Included in all trials as positive control to wheat blast.

d Overall costs (US\$/ha) considering commercial prices of the 2019/20 crop season and three applications (operational cost for each application used was US\$10.00/ha).
} 
The yield response $(\bar{D})$ was calculated directly after model fitting by subtracting estimated means of fungicide treatment and untreated check (Madden et al. 2016). For percent wheat blast control $(\bar{C})$, we calculated the differences of the estimated means of the logs $\left(\bar{L}_{I N D}\right)$ which equals the ratio of the two means (Paul et al. 2008). The $\bar{C}$ values and their $95 \%$ confidence intervals (CIs) were obtained by back-transforming $\bar{L}_{I N D}$ and the respective upper and lower limits of their 95\% CIs as described in Equation 2.

$$
\bar{C}=\left(1-\exp \left(\bar{L}_{I N D}\right)\right) \times 100
$$

Network inconsistency, or the extent to which different sources of evidence are compatible, is an important component to assess when performing a multi-arm network meta-analysis (Higgins et al. 2012). The most important source is a design-by-treatment interaction, also known as "design inconsistency", which provides a useful general framework for investigating inconsistency (Piepho 2014; Madden et al. 2016). To test for network inconsistency, we used a factorial-type ANOVA model to determine the significance of the treatment $\mathrm{x}$ design interaction, evaluated based on the Wald test statistic. The null hypothesis suggests that the network is consistent (Piepho 2014; Madden et al. 2016). Eight different designs (here design refers to the set of fungicide treatments in the trial) were found in the trials reporting both WBI and yield response (Table S1).
A

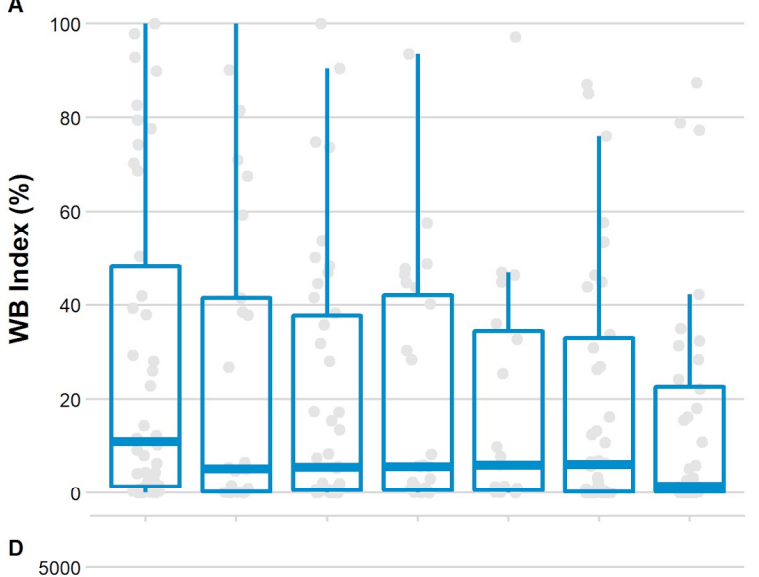

B

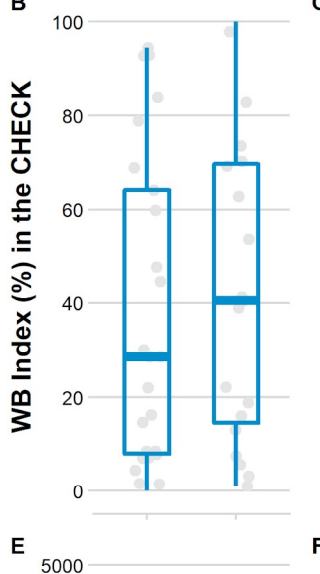

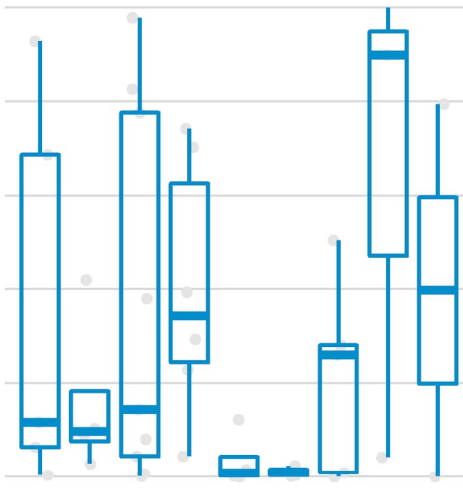
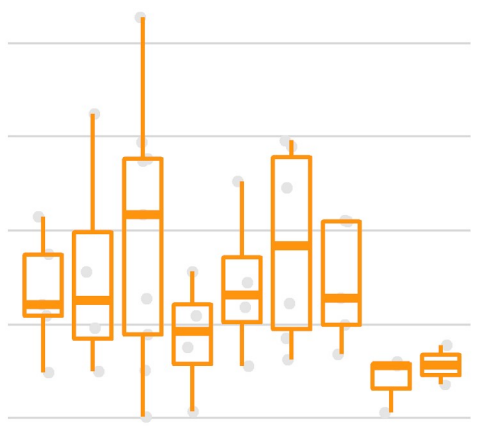

$v^{12} q^{13} q^{10} q^{10} q^{10} q^{10} q^{10} q^{19} q^{0^{0}}$

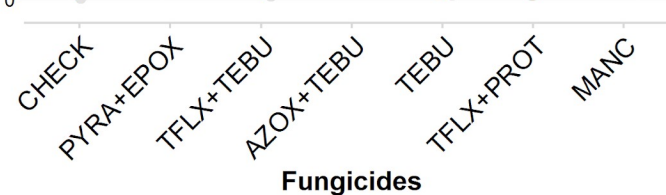

Crop Seasons

Fig. 2. Box plots depicting the means of wheat blast index (\%) and wheat grain yield $(\mathrm{kg} / \mathrm{ha})$ (across years and locations) of the untreated (CHECK) and fungicide-treated plots (A-D); and the means of the same variables in the untreated plots within-region (B-E) and within-year (C-F) measured from a set of $\mathbf{4 4}$ field trials conducted from 2012 to 2020. Climatic regions defined in our study were: Tropical (DF, MT, MS, MG) and Subtropical (PR, SP). The thick horizontal line inside the box represents the median, the limits of the box represent the lower and upper quartiles, and the circles represent the yearly means of each treatment. See Table 1 for information on the fungicide treatments. 


\section{Moderator effects}

Categorical or continuous moderator variables that could explain, at least a portion of the heterogeneity of the effects across trials, were included in the network model (Equation 1) (Madden et al. 2016). The expanded model is given by

$$
Y_{i} \sim N\left(\mu+\delta_{i}, \Sigma+S_{i}\right)
$$

where $\delta_{i}$ is the vector representing the moderator variable effect for the $i$ th study (Paul et al. 2010). All other terms were defined previously at Equation 1.

As categorical, we created baselines for WBI and wheat grain yield based on the median of the mean values in the untreated check. For baseline disease index, the trials were divided into two groups, representing WBI_low $(\mathrm{WBI}<10 \%)$ and WBI_high (WBI $\geq 10 \%$ ) disease scenarios. The baseline yield was defined as YLD_low ( $<1200 \mathrm{~kg} / \mathrm{ha})$ or YLD_high $(\geq 1200 \mathrm{~kg} / \mathrm{ha})$ based on the median yield in the untreated check plot. Finally, we created an additional categorical variable based on climatic region where trials were grouped into Tropical (DF, MT, MS, MG) and Subtropical (PR, SP) regions as mentioned previously (Fig. 1). As continuous moderators, year was included in the model to check whether there was any trend of decline in fungicide efficacy or yield response over time (Dalla Lana et al. 2018).

The moderator variables included in the model were tested using a Wald-type chi-square test to determine if their inclusion directly affected the differences in logs of WBI and the untransformed yield values (Paul et al. 2008).

\section{Economic analysis}

Monte Carlo simulations were used to produce distributions of profits that each fungicide would have in each region (Subtropical and Tropical) based on their respective yield return $(D, \mathrm{~kg} / \mathrm{ha})$. The profit was calculated from the difference between the income ( $I$, USS/ha) and spraying cost (USS/ha), where $I$ is the product of $D$ and the wheat price $(P, \mathrm{USS} / \mathrm{kg})$. $D$ was assumed to follow a truncated normal distribution between 0 and $+\infty, D \sim T N\left(\mu_{D}, \sigma_{D}\right)$, where $\mu_{D}$ is the mean $D$ given by the estimated yield return $(\bar{D})$, and the $\sigma_{D}$ is the standard deviation which was given by standard error of $\underline{D}$, i.e. $S E(\bar{D})$. $P$ was assumed to follow a Gamma distribution, $P \sim \operatorname{Gamma}(\alpha, \beta)$, where $\alpha$ and $\beta$ are the shape and the rate parameters, respectively. To estimate these parameters, we gathered wheat price historical data from the AGROLINK database from January 2012 to May 2021 (AGROLINK 2021). Two methods were used to estimate the parameters: nonlinear regression using least-squares to fit the empirical cumulative distribution function to the gamma cumulative distribution function, and maximum likelihood estimation (MLE). We used a two-sample Kolmogorov-Smirnov test (KS-test) to evaluate the best estimates, in which the parameters that produce distribution with higher P-value in the KS-test against the empirical cumulative distribution.

The overall fungicide spraying cost $(x)$ accounting for fungicide price of $2019 / 20$ crop season, and operational cost of $10 \mathrm{US/application}$ for three applications are described in Table 1. The spraying cost $\left(S_{c}\right)$ was assumed to follow be uniformly distributed with values varying from $5 \%$ above and below the overall fungicide spraying cost $(x)$, therefore, $S_{c} \sim$ Unif $(0.95 x, 1.05 x)$.

We ran a total of 50,000 Monte Carlo simulations for each variable $\left(P, D\right.$, and $\left.S_{c}\right)$, the distribution of $I$ was obtained and then the distribution of profits was derived. Break-even probabilities were calculated as the relative frequency of values that the income was equal to or higher than the fungicide spraying cost $(I \geq C)$.

\section{Results}

\section{Wheat blast index (WBI) and yield data at the trial level}

There was considerable variation in WBI and grain yield in the untreated plots across seasons, regions, and locations/trials (each dot in Fig. 2 represents a single trial). WBI in the untreated plots of the trials ranged from 0 to $100 \%$ (median $11.06 \%$ ). The median WBI was higher $(12.3 \%)$ in the Tropical than in the Subtropical $(8.1 \%$ ) region (Fig. 2 B). Across growing seasons, the highest $(89.8 \%)$ and the lowest $(0.8 \%)$ WBI medians in the untreated check were recorded in the 2019 and 2017 seasons, respectively (Fig. 2 C).

Baseline yield ranged from 15.6 to $4,276.2 \mathrm{~kg} / \mathrm{ha}$ (median $=1,203.5 \mathrm{~kg} / \mathrm{ha}$ ) across the trials. The median yield was lower in the Tropical $(1,000 \mathrm{~kg} / \mathrm{ha})$ than in the Subtropical region $(1,281 \mathrm{~kg} / \mathrm{ha})$ (Fig. 2E). The highest median yield (2,173 kg/ha) was observed in 2014 and the lowest (571.6 kg/ha) in the 2019 crop season (Fig. 2F). As expected, lower WBI and higher grain yield was observed in the fungicide treatments compared with the untreated check (Fig. 2A-D). 
Table 2. Overall means of Wheat Blast control efficacy $(\bar{C})$ and wheat yield response $(\bar{D})$ for each fungicide treatment, relative to the untreated check, not conditioned (Overall) and conditioned (moderator analysis) to two climatic regions (Tropical [DF, MT, MS, MG] and Subtropical [PR, SP]), conducted during nine years (2012-2020) across six Brazilian states.

\begin{tabular}{|c|c|c|c|c|c|c|c|c|c|c|c|}
\hline \multirow[b]{2}{*}{ Fungicide $^{\mathrm{a}}$} & \multirow[b]{2}{*}{ Region } & \multicolumn{5}{|c|}{ Control efficacy (\%) } & \multicolumn{5}{|c|}{ Yield return (Kg/ha) } \\
\hline & & $k^{\mathrm{b}}$ & $\bar{C}$ & $\mathrm{CI}_{\mathrm{L}}^{\mathrm{c}}$ & $\mathrm{CI}_{\mathrm{U}^{\mathrm{c}}}$ & P-value ${ }^{\mathrm{d}}$ & $k^{\mathrm{b}}$ & $\bar{D}$ & $\mathrm{CI}_{\mathrm{L}}^{\mathrm{c}}$ & $\mathrm{CI}_{U^{c}}$ & P-value ${ }^{\mathrm{d}}$ \\
\hline \multirow[t]{3}{*}{ MANC } & Overall & 33 & 58.0 & 49.8 & 64.8 & \multirow[b]{3}{*}{0.0011} & 35 & 420.1 & 315.6 & 524.6 & \multirow[b]{3}{*}{0.0027} \\
\hline & Tropical & 13 & 42.1 & 26.1 & 54.7 & & 14 & 241.3 & 94.7 & 387.9 & \\
\hline & Subtropical & 20 & 66.5 & 40.6 & 81.1 & & 21 & 532.1 & 195.3 & 868.9 & \\
\hline \multirow[t]{3}{*}{ TFLX + PROT } & Overall & 39 & 53.9 & 44.6 & 61.6 & & 42 & 299.7 & 221.9 & 377.5 & \\
\hline & Tropical & 15 & 40.8 & 22.9 & 54.5 & \multirow[b]{2}{*}{0.0262} & 17 & 149.3 & 44.7 & 254.0 & \multirow[b]{2}{*}{0.0004} \\
\hline & Subtropical & 24 & 59.9 & 26.4 & 78.2 & & 25 & 396.5 & 154.5 & 638.4 & \\
\hline \multirow[t]{3}{*}{ TEBU } & Overall & 18 & 53.6 & 43.2 & 62.1 & \multirow[b]{3}{*}{0.3076} & 19 & 319.5 & 221.6 & 417.3 & \multirow[b]{3}{*}{0.1836} \\
\hline & Tropical & 8 & 47.2 & 28.2 & 61.1 & & 9 & 209.0 & 52.7 & 365.3 & \\
\hline & Subtropical & 10 & 56.9 & 13.3 & 78.6 & & 10 & 351.1 & -14.6 & 716.8 & \\
\hline \multirow[t]{3}{*}{ AZOX + TEBU } & Overall & 18 & 54.8 & 43.5 & 63.9 & & 19 & 301.5 & 215.7 & 387.2 & \\
\hline & Tropical & 7 & 47.1 & 26.2 & 62.1 & \multirow[b]{2}{*}{0.2704} & 8 & 157.0 & 52.7 & 261.3 & \multirow[b]{2}{*}{0.0006} \\
\hline & Subtropical & 11 & 58.4 & 10.9 & 80.6 & & 11 & 410.3 & 162.2 & 658.4 & \\
\hline \multirow[t]{3}{*}{ TFLX + TEBU } & Overall & 39 & 52.2 & 43.5 & 59.6 & \multirow[b]{3}{*}{0.0685} & 42 & 245.3 & 172.9 & 317.8 & \multirow[b]{3}{*}{0.0028} \\
\hline & Tropical & 15 & 42.4 & 26.1 & 55.2 & & 17 & 123.9 & 25.7 & 222.1 & \\
\hline & Subtropical & 24 & 57.4 & 24.3 & 76.0 & & 25 & 323.4 & 94.6 & 552.2 & \\
\hline \multirow[t]{3}{*}{ PYRA + EPOX } & Overall & 19 & 43.2 & 31.8 & 52.8 & & 22 & 181.1 & 114.8 & 247.5 & \\
\hline & Tropical & 8 & 24.2 & 2.81 & 40.9 & \multirow[b]{2}{*}{0.0037} & 10 & 29.1 & -49.8 & 108.1 & \multirow[b]{2}{*}{$<0.0001$} \\
\hline & Subtropical & 11 & 54.3 & 17.5 & 74.7 & & 12 & 255.0 & 65.4 & 444.6 & \\
\hline
\end{tabular}

a See Table 1 for complete information on the fungicides;

${ }^{\mathrm{b}}$ number of trials that each fungicide was evaluated.

${ }^{c}$ upper $\left(\mathrm{CI}_{\mathrm{U}}\right)$ and lower $\left(\mathrm{CI}_{\mathrm{L}}\right)$ limits of the $95 \%$ confidence interval around $\bar{C}$ and $\bar{D}$.

${ }^{\mathrm{d}}$ probability value (significance level) for the effect of fungicide on disease reduction and yield response (at the selected climatic regions).

\section{Overall meta-analytic estimates of control efficacy and yield response}

For all fungicides tested in the meta-analytic model, the overall WBI $\log$ response ratio $\left(\bar{L}_{I N D}\right)$ differed $(\mathrm{P}<$ 0.0001) from the untreated CHECK (Table S2). Overall estimates of percent control efficacy $(\bar{C})$, obtained from back-transforming differences of the estimates of log of WBI $\left(\bar{L}_{I N D}\right)$ between the fungicide-treated and untreated plots, ranging from $43.2 \%$ and $58.0 \%$. MANC, AZOX + TEBU, TFLX + PROT, TEBU, and TFLX + TEBU reduced WBI by at least $52 \%$ and did not differ significantly among them $(P>0.12)$ based on linear contrasts. PYRA + EPOX was the least effective treatment (43.2\%) and did not differ from TEBU (53.5\%; $\mathrm{P}=0.07)$ and TFLX + TEBU $(52.2 \% ; \mathrm{P}=0.06)($ Table $\mathrm{S} 2)$. The difference in percent control efficacy between the most and least effective fungicide was 14.8 percent points (Table 2). The Wald test for the treatment $\mathrm{x}$ design interaction showed that the network was consistent $(P=0.70)$.

Yield response $(\bar{D})$ was significantly higher $(\mathrm{P}<$ 0.0001) in all single a.i. and dual mixtures compared with the untreated CHECK (Table S3). The mean estimates of $\bar{D}$ ranged from $181.15 \mathrm{~kg} /$ ha to 420.10 $\mathrm{kg} / \mathrm{ha}$. The two single a.i. treatments, MANC (420.10 $\mathrm{kg} / \mathrm{ha})$ and TEBU (319.46 kg/ha) provided the greatest yield response, and linear contrasts showed no difference between them $(P=0.065)$. These were followed by AZOX + TEBU (301.48 $\mathrm{kg} / \mathrm{ha})$ and TFLX+PROT (299.73 kg/ha), which were not different between them $(P=0.90)$, but differed from TFLX+TEBU $(245.34 \mathrm{~kg} / \mathrm{ha} ; \mathrm{P}<0.0001)$. All fungicides differed from PYRA + EPOX $(181.15 \mathrm{~kg} / \mathrm{ha})$ with regards to yield response. The difference between the highest and lowest yield response among the treatments was 238.95 $\mathrm{kg} /$ ha (Table 2, Table S3). The Wald test for the 
treatment $x$ design interaction showed that the network was inconsistent, meaning that results were dependent on the design $(P=0.01)$.

\section{Effect of moderator variables}

The categories of WBI and wheat grain yield as baselines did not affect WBI or yield $(P>0.05)$. Similarly, year did not affect wheat grain yield $(P=0.26)$ or WBI $(P$ $=0.74)$, suggesting no decline in fungicide efficacy or yield response over time.

Based on the Wald test $(P<0.0001)$, the expanded model including the categorical moderator variable region differed statistically from the simpler model for both disease index and yield response. The control efficacy in the Subtropical region was numerically higher compared to the Tropical region for all treatments. A difference of at least 19.1 percent points in $\bar{C}$ between regions was significant $(\mathrm{P}<0.05)$ for three fungicides (PYRA + EPOX, TFLX + PROT and MANC) (Table 2). Similarly, yield response from the use of fungicides was generally higher in the Subtropical than in the Tropical region. There was a statistical difference in $\bar{D}$ between regions for all fungicides, except TEBU (P $=0.1836)$. Significant differences in yield responses between regions ranged from 200 to $291 \mathrm{~kg} / \mathrm{ha}$ (Table 2).

In general, there was a similar pattern in the relationship between yield response and fungicide efficacy among regions. The treatment leading to the greatest mean yield response in both Tropical and Subtropical regions was MANC (Fig. 3). Similarly, MANC was the numerically most effective treatment in reducing disease index in the Subtropical region. For the Tropical region, TEBU and AZOX + TEBU exhibited a high control efficacy ( 47\%). Again, PYRA + EPOX provided the least yield response in both Tropical and Subtropical regions (Fig. 3).

\section{Profits and break-even probabilities}

Estimates of parameters of the Gamma distribution for the distribution of wheat prices for the 2012-2020 period that produced higher P-value in the KS-test were obtained using non-linear regression $(\mathrm{P}$-value $=$ 0.9375). The P-value in the KS-test for the parameters estimated using MLE was 0.11. The estimates of the shape $(\alpha)$ and the rate $(\beta)$ parameters were 19.4 and 0.54 , respectively.

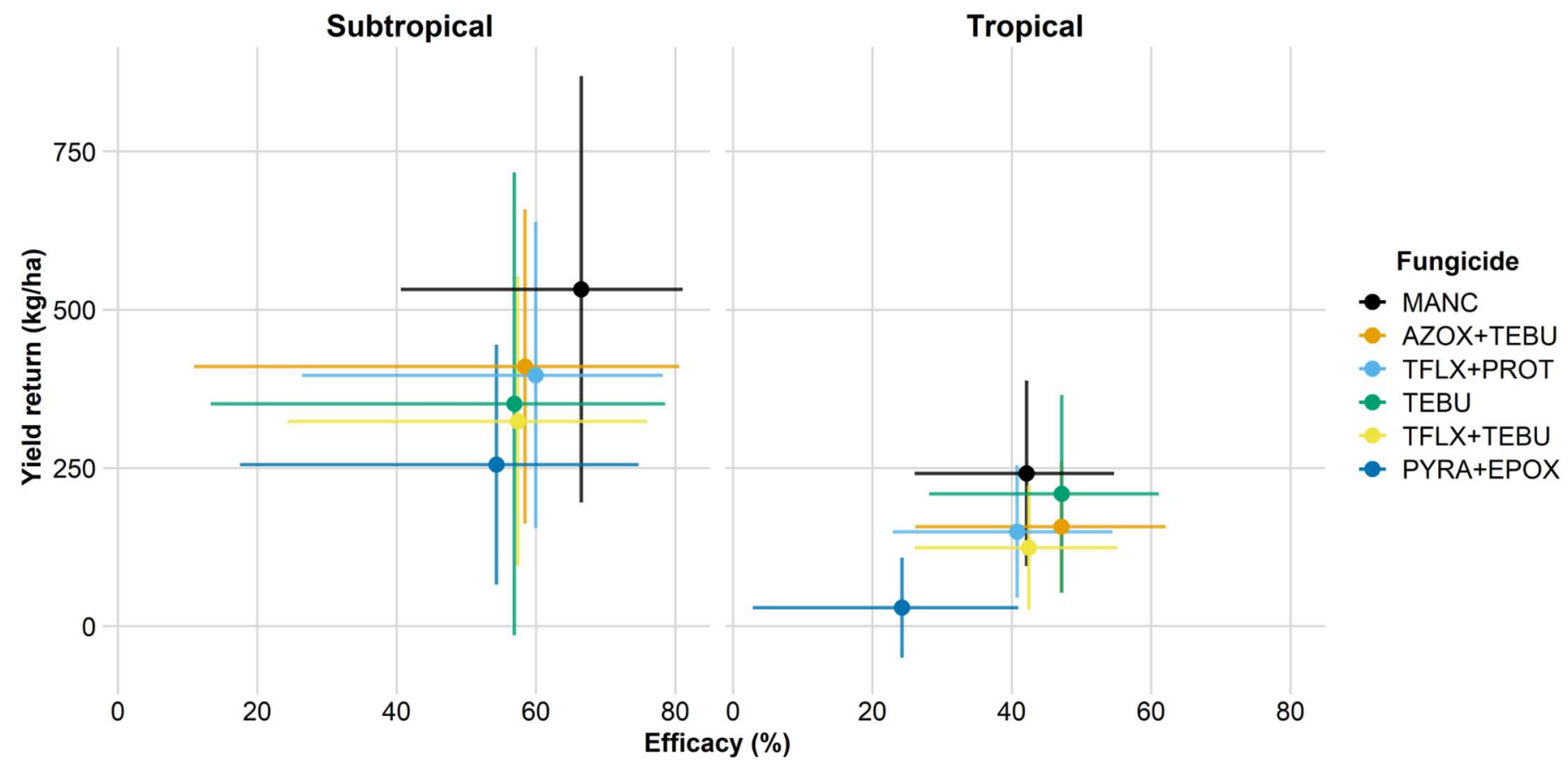

Fig. 3. Relationship between fungicide efficacy and wheat grain yield relative to the untreated check, for six selected fungicide treatments evaluated during nine years (2012 to 2020) across 44 field trials conducted across six Brazilian states (PR, SP, DF, MT, MS, and MG). Bars show the upper and lower limits of $95 \%$ confidence intervals around point estimates for both responses. See Table 1 for complete information on the evaluated fungicides. 
Overall, fungicides were more profitable in the subtropical region, with break-even probabilities, $P(I \geq C)$, values higher than 0.99 for all fungicides (Fig. 4). In this region, the most profitable fungicide was MANC, with a mean profit of US\$269.73/ha. The least profitable fungicide in the subtropical region was PYRA+EPOX, with a mean profit of US\$118.17/ha. In the tropical region, break-even probabilities of fungicides were much lower than those obtained in the subtropics. The $P(I \geq C)$ values ranged from 0.17 (PYRA+EPOX) to 0.97 (MANC) (Fig. 4). The most profitable fungicide was again MANC, with a mean profit of US\$95.00/ha and the least profitable was PYRA+EPOX, with a negative mean profit of US\$17.66/ha.

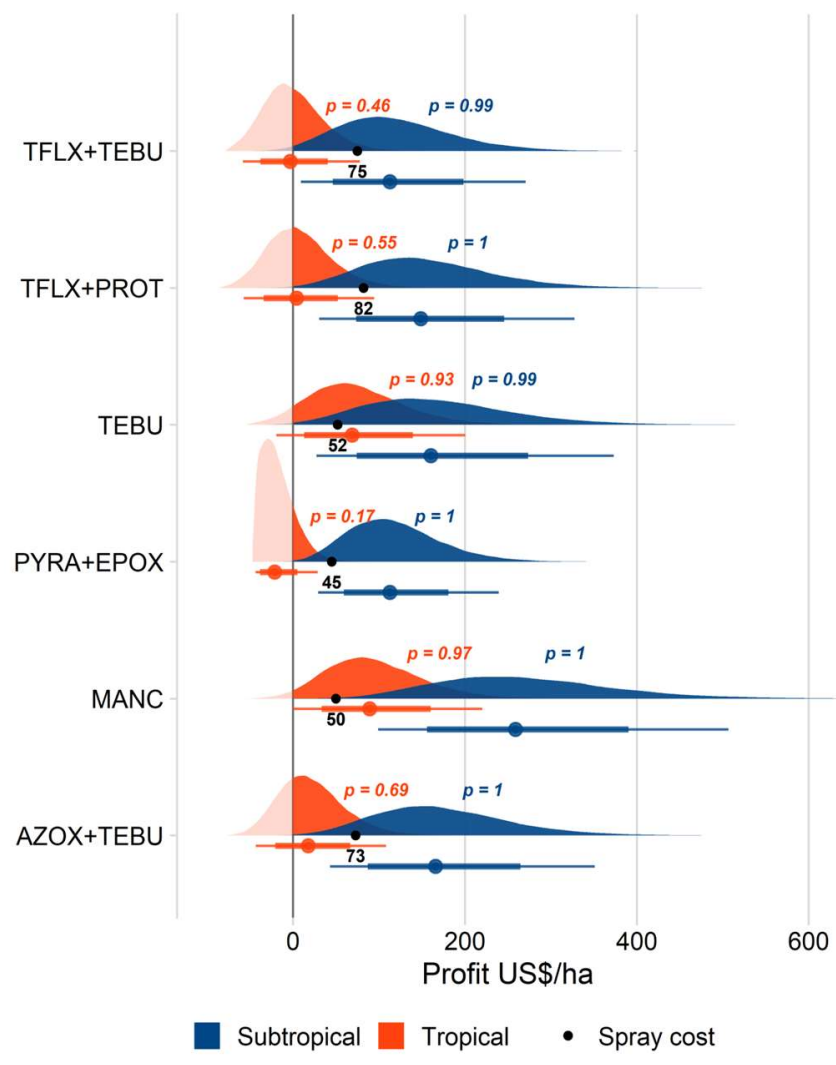

Fig. 4. Half-eye plots (density and point intervals) of profits $(50,000$ simulation runs) based on the metaanalytic estimate of yield return $(\mathrm{kg} / \mathrm{ha})$ for six fungicide treatments conditioned of two climatic regions (Tropical and Subtropical) evaluated during nine crop-seasons (2012 to 2020). The thinner error bars depict the 2.5 and 97.5 percentile of the distribution, while the thicker error bars represent 25 and 75 percentiles, and the solid-colored point gives the median profit for each fungicide and region. $p$ gives the break-even probabilities, i.e, income greater than the cost of each fungicide in each respective region. The numbered black dots represent the spraying costs in US\$/ha of each fungicide.

\section{Discussion}

This study provides an updated summary of the effects of different chemistry applied sequentially (three sprays starting at the heading stage) for managing wheat blast. For such, we gathered data from 44 uniform field trials conducted during nine growing seasons (2012-2020) across several wheat-producing states in Brazil. Despite previous reports using metaanalysis (17 trials conducted from 2012 to 2014) also with the goal of comparing fungicide treatments (Cruz et al. 2019), this work is considering the larger number of environments for wheat blast control using fungicides, reinforcing its importance.

Results of our analysis corroborate one of the main findings of that study for the Brazilian trials, which also reported a similar performance among the QoI+DMI premixes and a protectant fungicide. Similarly, a recent single field experiment (2019/20 season) conducted in Bangladesh reported a relatively high efficacy (65\%) for MANC, which was close to our upper limit (95\% confidence interval) estimate (Roy et al. 2020). The yield gain from using MANC in the Bangladeshi study $(744 \mathrm{~kg} / \mathrm{ha}$ ) was within the expected gain (close to the upper limit) of estimated trials conducted in the Subtropical region of Brazil. Among several differences in experimental conditions, it is worth noting the difference in the concentration of MANC that was a bit higher $(800 \mathrm{~g} / \mathrm{kg})$ in that study compared with the recommended dose used in the Brazilian experiments $(750 \mathrm{~g} / \mathrm{kg})$, which may explain the higher levels of efficacy and yield response.

Commercial premixes of QoI+DMI have been tested more extensively than MANC in independent research. For instance, in the meta-analysis conducted by Cruz et al. (2019), the authors reported a relatively high control efficacy (58 to 68\%) for picoxystrobin + cyproconazole, trifloxystrobin + tebuconazole, azoxystrobin + cyproconazole and pyraclostrobin + epoxiconazole applied twice across six field trials conducted in Bolivia from 2014 to 2015. Average yield responses obtained from applying those premixes in that study were extremely high, in the magnitude of 1,834 kg/ha (Cruz et al. 2019).

In Brazil, contrary to our findings, replicated field studies have reported higher levels of efficacy of PYRA+EPOX - ranging from $60 \%$ (Pagani et al. 2014) to 85\% (Rios et al. 2016), compared with our estimates (95\%CI 31 to $52 \%$ ) regardless of the region. Overall, we found that this commercial premix performed the poorest among all treatments. Nevertheless, improved efficacy similar to those obtained in Bolivia, using PYRA + EPOX, can be expected especially in the southern region of Brazil, but with a high level of uncertainty (95\% CI $17 \%$ to $74 \%$ ). 
Tebuconazole is an affordable option widely used by Brazilian growers not only for controlling wheat blast, but also for managing other important wheat diseases such as Fusarium head blight (Machado et al. 2017; Duffeck et al. 2020; Barro et al. 2020). The mean estimates of TEBU applied solo (54\%) as well as the premix TFLX + TEBU (52\%) reported in our metaanalysis were very similar to a two-year study (TEBU = $57 \%$; TFLX + TEBU $=50 \%$ ) conducted in Midwest Brazil during 2010 and 2011 crop seasons (Pagani et al. 2014). Moreover, the yield responses from using the TEBU based fungicides reported in that study $(\sim 400 \mathrm{~kg} / \mathrm{ha})$ (Pagani et al. 2014) were within the expected range, mainly for trials conducted in the Subtropics where yield response was greater than in the Tropical region.

In general, the levels of control were superior and, on average, 18 percent points greater in the Subtropical region (54 to 66\%) compared with the Tropical region (24 to $47 \%$ ). The only exception was tebuconazole fungicide for which efficacy was not influenced by region. Our findings demonstrated a similar pattern of disease control related by single studies carried out at Tropical $(60 \%)$ or Subtropical trials (85\%) (Pagani et al. 2014; Rios et al. 2016).

Results of our profitability analysis using the means and respective uncertainty of the estimates of yield return showed that, regardless of the region, the most profitable fungicide was MANC, given its lower price, and similar efficacy and yield response compared with the premixes. Although mancozeb was introduced in 1962, it is still important in the fungicide market worldwide and known to be a cost-effective fungicide (Gullino et al. 2010; Thind and Hollomon 2018). In fact, the probabilities of breaking even on costs of the commercial premixes of fungicides were generally lower, especially in the Tropical region, for all premixes (which are most costly) than MANC and TEBU, for which high break-even probabilities $(>92 \%)$ are expected.

In Brazilian tropical wheat growing region it is important to mention that there are two different systems able to produce wheat contrasting for the disease presence. The first one is in an irrigated system with the higher yield and quality wheat production in Brazil and where the blast is not a big concern and the dry condition where we had the trials. In this case the planting date range from February to May (end of summer to begin of autumn) having better environmental conditions for the development of the disease.

The combination of resistant cultivars and fungicide protection has been explored to improve disease management. For instance, Rios et al. (2016) found the greatest overall efficacy in reducing wheat blast incidence $(\sim 73 \%)$ and severity ( $\sim 94 \%)$ by applying PYRA + EPOX in a moderate resistant cultivar (BR-18) compared to a susceptible one (Guamirin). Moreover, the combination of PYRA + EPOX and BR-18 resulted in the highest mean yield (1,135 kg/ha) (Rios et al. 2016).

The use of premixes of single-site amended with multi-site fungicides is an ongoing strategy to improve wheat blast control. Preliminary data from the uniform fungicide trials (Santana et al. 2019b, 2019a, 2020a, 2020b) have shown benefits from adding a multi-site fungicide (mancozeb) in the mixture and more data will become available in the near future to confirm this observation. Additionally, the use of multi-site fungicides is important for managing fungicide resistance (FRAC-BR 2021). In fact, less sensitive PoT populations to QoIs and DMIs in Brazil have been reported, associated with mutations in cytochrome b gene (mainly G143A substitution) (Castroagudín et al. 2015) or CYP51 gene (several mutation points) (Dorigan et al. 2019; Poloni et al. 2021). However, using a relatively long time series we did not find evidence of a decline in fungicide efficacy over the years for all commercial premixes amended with QoI as well as TEBU applied solo. Whether QoIs are less effective or losing efficacy over the years could not be inferred given that none of the fungicides had QoI as a sole active ingredient. If that happens to be true and confirmed by field research, it is possible that the DMI component is responsible for the control. Further research in this area will be important to contribute to the debate around the risk associated with the use of strobilurins for wheat blast control (Castroagudín et al. 2015; Oliveira et al. 2015; Poloni et al. 2021).

In conclusion, the definition of the best options in fungicide programs for managing wheat blast should take into account region-specific factors that affect the performance of fungicides and also the need to extend control to other diseases, a case where QoI + DMI premixes have found use not only in Brazil (Blandino et al. 2006; Willyerd et al. 2012; Barro et al. 2017; Paul et al. $2018 \mathrm{~b})$. Management tactics such as application of sitespecific fungicides amended with multi-site fungicides programs; use of adapted wheat cultivars carrying resistance genes against blast; and shifts in sowing time to escape conducive blast weather at heading stage should be considered as integrated management against wheat blast. Overall, this work demonstrated the profitability of site-specific and multi-site fungicides, their efficacy, and yield return by controlling wheat blast in a high conductive region (Tropical) and a moderately conductive (Subtropical) to blast occurrence, which may aid during decisionmaking when defining fungicide programs. 


\section{Acknowledgements}

The first and senior author acknowledges the financial support provided by the Conselho Nacional de Desenvolvimento Científico e Tecnológico (CNPq/Brazil) for scholarship and research fellowship (PQ-306857/2015-4), respectively. We also acknowledge the financial support provided by the Fundação de Amparo à Pesquisa do Estado de Minas Gerais (Fapemig/Brazil) for a research grant (APQ03945-16). All other authors are thankful to their institutions and teams for providing the support during the conduction of field experiments and collection of the data.

\section{Data availability statement}

The data and R scripts that support the findings of this study are openly available in the Open Science Framework project at osf.io/y $7 \mathrm{sgd} /$. A website was generated to better visualize the scripts where all data and analyses are documented and reproducible (git.io/JGVCM).

\section{Author's contribution}

JPA and JPB contributed equally to this study. JPA, JPB and EMD conceived the idea, analysed the data and wrote the manuscript. KSA analysed the data and wrote the manuscript. FMS planned and coordinated the experiments; JMVP, JLNM, DL, GAMT, CCS, CDSS, ACPG, AABS, CAS, DFC, MAOC, TDNM, DRA, AAPC, LSOM, CMU, WV, and RCSG conducted the field trials and shared the data. All authors provided feedback and approved the final manuscript.

\section{Conflict of interests}

The authors declare that they have no conflict of interests.

\section{Literature Cited}

AGROFIT. 2021. Ministério da Agricultura, Pecuária e Abastecimento. Available http://agrofit.agricultura.gov.br/agrofit_cons/principal_agrof it_cons [Accessed March 17, 2021].

AGROLINK. 2021. O Portal do conteúdo Agropecuário. Confira: Noticias atualizadas, Previsão do tempo, cotações, sistemas especialistas de produtos agro, Colunistas, Classificados gerais. Available at: https://www.agrolink.com.br / [Accessed March 19, 2021].
Barro, J. P., Forte, C. T., Trentin, D., Scariot, M., and Milanesi, P. M. 2017. Effectiveness of different fungicide formulations and number of applications in controlling wheat leaf rust. Summa Phytopathol. 43:276-280.

Barro, J. P., Meyer, M. C., Godoy, C. V., Dias, A. R., Utiamada, C. M., Jaccoud Filho, D. de S., et al. 2019. Performance and Profitability of Fungicides for Managing Soybean White Mold: A 10-Year Summary of Cooperative Trials. Plant Dis. 103:2212-2220.

Barro, J., Santana, F. M., Machado, F. J., Duffeck, M. R., Lau, D. Sbalcheiro, C. C., et al. 2020. Are DMI+QoI Fungicide Premixes During flowering Worthwhile for Fusarium head blight Control in Wheat? A Meta-analysis. Plant Dis. Available at: https://apsjournals.apsnet.org/doi/abs/10.1094/PDIS-09-202096-RE [Accessed April 23, 2021].

Blandino, M., Minelli, L., and Reyneri, A. 2006. Strategies for the chemical control of Fusarium head blight: Effect on yield, alveographic parameters and deoxynivalenol contamination in winter wheat grain. Eur. J. Agron. 25:193-201.

Castroagudín, V. L., Ceresini, P. C., de Oliveira, S. C., Reges, J. T. A., Maciel, J. L. N., Bonato, A. L. V., et al. 2015. Resistance to QoI Fungicides Is Widespread in Brazilian Populations of the Wheat Blast Pathogen Magnaporthe oryzae. Phytopathology. 105:284294.

Ceresini, P. C., Castroagudín, V. L., Rodrigues, F. Á., Rios, J. A., Aucique-Pérez, C. E., Moreira, S. I., et al. 2019. Wheat blast: from its origins in South America to its emergence as a global threat: Wheat Blast. Mol. Plant Pathol. 20:155-172.

Ceresini, P. C., Castroagudín, V. L., Rodrigues, F. Á., Rios, J. A., Eduardo Aucique-Pérez, C., Moreira, S. I., et al. 2018. Wheat Blast: Past, Present, and Future. Annu. Rev. Phytopathol. 56:427-456.

Chakraborty, M., Mahmud, N. U., Gupta, D. R., Tareq, F. S., Shin, H. J. and Islam, T. 2020a. Inhibitory Effects of Linear Lipopeptides From a Marine Bacillus subtilis on the Wheat Blast Fungus Magnaporthe oryzae Triticum. Front. Microbiol. 11 Available at: https://www.frontiersin.org/articles/10.3389/fmicb.2020.006 65/full [Accessed November 9, 2020].

Chakraborty, M., Mahmud, N. U., Muzahid, A. N. M., Rabby, S. M. F. and Islam, T. 2020b. Oligomycins inhibit Magnaporthe oryzae Triticum and suppress wheat blast disease. PLOS ONE. 15:e0233665.

Coelho, M. A. de O., Torres, G. A. M., Cecon, P. R., and Santana, F. M. 2016. Sowing date reduces the incidence of wheat blast disease. Pesqui. Agropecuária Bras. 51:631-637.

Comissão Brasileira de Pesquisa de Trigo e Triticale. 2020. Informações Técnicas para Trigo e Triticale. 13th ed. Passo Fundo, RS. Brasil: Biotrigo Genética.

Cruppe, G., Cruz, C. D., Peterson, G., Pedley, K., Asif, M., Fritz, A., et al. 2020. Novel Sources of Wheat Head Blast Resistance in Modern Breeding Lines and Wheat Wild Relatives. Plant Dis. 104:35-43.

Cruz, C. D., Santana, F. M., Todd, T. C., Maciel, J. L. N., Kiyuna, J., Baldelomar, D. F., et al. 2019. Multi-environment assessment of fungicide performance for managing wheat head blast (WHB) in Brazil and Bolivia. Trop. Plant Pathol. 44:183-191.

Cruz, C. D., and Valent, B. 2017. Wheat blast disease: danger on the move. Trop. Plant Pathol. 42:210-222.

Cruz, M. F. A., Rios, J. A., Araujo, L., and Ávila Rodrigues, F. 2016. Infection process of Pyricularia oryzae on the leaves of wheat seedlings. Trop. Plant Pathol. 41:123-127.

Dalla Lana, F., Paul, P. A., Godoy, C. V., Utiamada, C. M., da Silva, L. H. C. P., Siqueri, F. V., et al. 2018. Meta-Analytic Modeling of the Decline in Performance of Fungicides for Managing Soybean Rust after a Decade of Use in Brazil. Plant Dis. 102:807-817.

Dorigan, A. F., Carvalho, G. D., Poloni, N. M., Negrisoli, M. M., Maciel, 
J. L. N., and Ceresini, P. C. 2019. Resistance to triazole fungicides in Pyricularia species associated with invasive plants from wheat fields in Brazil. Acta Sci. Agron. 41:39332.

Duffeck, M. R., Alves, K. S., Machado, F. J., Esker, P. D., and Del Ponte, E. M. 2020. Modeling Yield Losses and Fungicide Profitability for Managing Fusarium Head Blight in Brazilian Spring Wheat. Phytopathology®. 110:370-378.

FRAC-BR. 2021. Comitê de Ação a Resistência a Fungicidas. Frac-Br. Available at: https://www.frac-br.org [Accessed May 31, 2021].

Goulart, A. C. P., and Paiva, A. 1993. Evaluation of fungicides for control of wheat (Triticum aestivum L.) blast (Pyricularia grisea), 1991. In Annual Wheat Newsletter, Fort Collins: Department of Agronomy, Colorado State University.

Goulart, A. C. P., and Paiva, F. de A. 2000. Avaliação de Perdas no Rendimento de Grãos de Trigo Causadas por Pyricularia grisea, no Período de 1988 a 1992, em Mato Grosso do Sul. 7th ed. Dourados/MS: Embrapa.

Goulart, A. C. P., Paiva, F., and Mesquita, A. N. 1990. Occurrence and losses caused by wheat (Triticum aestivum L.) blast (Pyricularia oryzae Cav.) in the state of Mato Grosso do Sul, in 1988. In Annual Wheat Newsletter, Fort Collins: Department of Agronomy, Colorado State University.

Gullino, M. L., Tinivella, F., Garibaldi, A., Kemmitt, G. M., Bacci, L., and Sheppard, B. 2010. Mancozeb: Past, Present, and Future. 94:12.

Higgins, J. P. T., Jackson, D., Barrett, J. K., Lu, G., Ades, A. E., and White, I. R. 2012. Consistency and inconsistency in network metaanalysis: concepts and models for multi-arm studies. Res. Synth. Methods. 3:98-110.

Igarashi, S., Utiamada, C. M., Igarashi, L. C., Kazuma, A. H., and Lopes, R. 1986. Occurrence of Pyricularia sp. in wheat (Triticum aestivum L.) in the State of Parana, Brazil. Fitopatol. Bras. 11:351-352.

Islam, M. T., Kim, K.-H., and Choi, J. 2019. Wheat Blast in Bangladesh: The Current Situation and Future Impacts. Plant Pathol. J. 35:110.

Machado, F. J., Santana, F. M., Lau, D., and Del Ponte, E. M. 2017. Quantitative review of the effects of triazole and benzimidazole fungicides on Fusarium head blight and wheat yield in Brazil. Plant Dis. 101:1633-1641.

Maciel, J. L. N., Danelli, A. L. D., Boaretto, C., and Forcelini, C. A. 2013. Diagrammatic scale for the assessment of blast on wheat spikes. Summa Phytopathol. 39:162-166.

Madden, L. V., Piepho, H.-P., and Paul, P. A. 2016. Statistical Models and Methods for Network Meta-Analysis. Phytopathology. 106:792-806.

Malaker, P. K., Barma, N. C. D., Tiwari, T. P., Collis, W. J., Duveiller, E., Singh, P. K., et al. 2016. First Report of Wheat Blast Caused by Magnaporthe oryzae Pathotype triticum in Bangladesh. Plant Dis. 100:2330-2330.

Oliveira, S. C. de, Castroagudín, V. L., Maciel, J. L. N., Pereira, D. A. dos S., and Ceresini, P. C. 2015. Resistência cruzada aos fungicidas IQo azoxistrobina e piraclostrobina no patógeno da brusone do trigo Pyricularia oryzae no Brasil. Summa Phytopathol. 41:298-304.

Pagani, A. P. S., Dianese, A. C., and Café-Filho, A. C. 2014. Management of wheat blast with synthetic fungicides, partial resistance and silicate and phosphite minerals. Phytoparasitica. 42:609-617.

Paul, P. A., Bradley, C. A., Madden, L. V., Dalla Lana, F., Bergstrom, G. C., Dill-Macky, R., et al. 2018a. Effects of Pre- and Post Anthesis Applications of Demethylation Inhibitor Fungicides on Fusarium Head Blight and Deoxynivalenol in Spring and Winter Wheat. Plant Dis. 102:2500-2510.

Paul, P. A., Bradley, C. A., Madden, L. V., Lana, F. D., Bergstrom, G. C., Dill-Macky, R., et al. 2018b. Meta-Analysis of the Effects of QoI and DMI Fungicide Combinations on Fusarium Head Blight and Deoxynivalenol in Wheat. Plant Dis. 102:2602-2615.

Paul, P. A., Lipps, P. E., Hershman, D. E., McMullen, M. P., Draper, M. A., and Madden, L. V. 2008. Efficacy of Triazole-Based Fungicides for Fusarium Head Blight and Deoxynivalenol Control in Wheat: A Multivariate Meta-Analysis. Phytopathology. 98:999-1011.

Paul, P. A., McMullen, M. P., Hershman, D. E., and Madden, L. V. 2010 Meta-Analysis of the Effects of Triazole-Based Fungicides on Wheat Yield and Test Weight as Influenced by Fusarium Head Blight Intensity. Phytopathology. 100:160-171.

Perelló, A. E., Martinez, I., Sanabria, A., Altamirano, R., and Sibole, J. V. 2017. Pathogenicity of isolates of Magnaporthe spp. from wheat and grasses infecting seedlings and mature wheat plants in Argentina. Plant Pathol. 66:1149-1161.

Piepho, H.-P. 2014. Network-meta analysis made easy: detection of inconsistency using factorial analysis-of-variance models. BMC Med. Res. Methodol. 14 Available at: https://bmcmedresmethodol.biomedcentral.com/articles/10.11 86/1471-2288-14-61 [Accessed March 25, 2020].

Poloni, N. M., Carvalho, G., Vicentini, S. N. C., Dorigan, A. F., Maciel, J. L. N., McDonald, B. A., et al. 2021. Widespread distribution of resistance to triazole fungicides in Brazilian populations of the wheat blast pathogen. Plant Pathol. 70:436-448.

R Core Team. 2021. R: A Language and Environment for Statistical Computing. Vienna, Austria: $\mathrm{R}$ Foundation for Statistical Computing. Available at: https://www.R-project.org/.

Rios, J. A., Rios, V. S., Paul, P. A., Souza, M. A., Araujo, L., and Rodrigues, F. A. 2016. Fungicide and cultivar effects on the development and temporal progress of wheat blast under field conditions. Crop Prot. 89:152-160.

Roy, K. K., Anwar, M. B., Mustarin, K.-E.-, Reza, M. M. A., Muzahid-ERahman, M., Malaker, P. K., et al. 2020. Evaluation of different fungicides (chemical, botanical and bio-agent) in controlling wheat blast in a blast prone area in Bangladesh. Arch. Phytopathol. Plant Prot. 0:1-9.

Santana, F. M., Lau, D., Sbalcheiro, C. C., Aguilera, J. G., Goulart, A. C. P., Sussel, A. A. B., et al. 2016a. Eficiência de fungicidas para o controle da brusone do trigo: resultados dos ensaios cooperativos safra 2013. Passo Fundo, RS. Brasil: Embrapa Trigo.

Santana, F. M., Lau, D., Sbalcheiro, C. C., Aguilera, J. G., Goulart, A. C. P., Sussel, A. A. B., et al. 2016b. Eficiência de fungicidas para o controle da brusone do trigo: resultados dos ensaios cooperativos safra 2014. Passo Fundo, RS. Brasil: Embrapa Trigo.

Santana, F. M., Lau, D., Sbalcheiro, C. C., Goulart, A. C. P., Custódio, A. A. P., Venâncio, W. S., et al. 2016c. Eficiência de fungicidas para controle de brusone de trigo: resultados dos ensaios cooperativos safra 2015. Passo Fundo, RS. Brasil: Embrapa Trigo.

Santana, F. M., Lau, D., Sbalcheiro, C. C., Goussain, R. C. S., Venancio, W. S., Custódio, A. A. P., et al. 2020a. Eficiência de fungicidas para controle de brusone de trigo: resultados dos ensaios cooperativos, safra 2018. Passo Fundo, RS. Brasil: Embrapa Trigo.

Santana, F. M., Lau, D., Sbalcheiro, C. C., Sussel, A. A. B., Goussain, R. C. S., Venancio, W. S., et al. 2019a. Eficiência de fungicidas para controle de brusone de trigo: resultados dos ensaios Cooperativos safra 2017. Passo Fundo, RS. Brasil: Embrapa Trigo.

Santana, F. M., Lau, D., Sbalcheiro, C. C., Sussel, A. A. B., Seixas, C. D. S., Venancio, W. S., et al. 2019b. Eficiência de fungicidas para controle da brusone de trigo: resultados dos ensaios cooperativos, safra 2016. Passo Fundo, RS. Brasil: Embrapa Trigo.

Santana, F. M., Lau, D., Sbalcheiro, C. C., Sussel, A. A. B., Venancio, W. S., Schipanski, C. A., et al. 2020b. Eficiência de fungicidas para controle de brusone de trigo: resultados dos ensaios cooperativos, safra 2019. Passo Fundo, RS. Brasil: Embrapa Trigo. 
Santana, F. M., Maciel, J. N., Lau, D., Cargnin, A., Seixas, C. D. S., Bassoi, M. C., et al. 2013. Eficiência de fungicidas para o controle da brusone do trigo: resultados dos ensaios cooperativos - safra 2011. Passo Fundo, RS. Brasil: Embrapa Trigo.

Santana, F. M., Maciel, J. N., Lau, D., Torres, G. A. M., Cargnin, A., Seixas, C. D. S., et al. 2014. Eficiência de fungicidas para o controle da brusone do trigo: resultados dos ensaios cooperativos - safra 2012. Passo Fundo, RS. Brasil: Embrapa Trigo.

Tembo, B., Mulenga, R. M., Sichilima, S., M'siska, K. K., Mwale, M., Chikoti, P. C., et al. 2020. Detection and characterization of fungus (Magnaporthe oryzae pathotype Triticum) causing wheat blast disease on rain-fed grown wheat (Triticum aestivum L.) in Zambia. PLOS ONE. 15:e0238724.

Thind, T. S., and Hollomon, D. W. 2018. Thiocarbamate fungicides: reliable tools in resistance management and future outlook: Thiocarbamate fungicides. Pest Manag. Sci. 74:1547-1551.

Tosa, Y., and Chuma, I. 2014. Classification and parasitic specialization of blast fungi. J. Gen. Plant Pathol. 80:202-209.
Urashima, A. S., Alves, A. F., Silva, F. N., Oliveira, D., and Gazaffi, R. 2017. Host range, mating type and population structure of Magnaporthe sp. of a single barley field in São Paulo state, Brazil. J. Phytopathol. 165:414-424.

Urashima, A. S., Leite, S. F., and Galbieri, R. 2007. Eficiência da disseminação aérea em Pyricularia grisea. Summa Phytopathol. $33: 275-279$

Viechtbauer, W. 2010. Conducting Meta-Analyses in R with the metafor Package. J. Stat. Softw. 36:1-48.

Willyerd, K. T., Li, C., Madden, L. V., Bradley, C. A., Bergstrom, G. C. Sweets, L. E., et al. 2012. Efficacy and Stability of Integrating Fungicide and Cultivar Resistance to Manage Fusarium Head Blight and Deoxynivalenol in Wheat. Plant Dis. 96:957-967.

Zadoks, J. C., Chang, T. T., and Konzak, C. F. 1974. A decimal code for the growth stages of cereals. Weed Res. 14:415-421. 


\section{Supplemental Material}
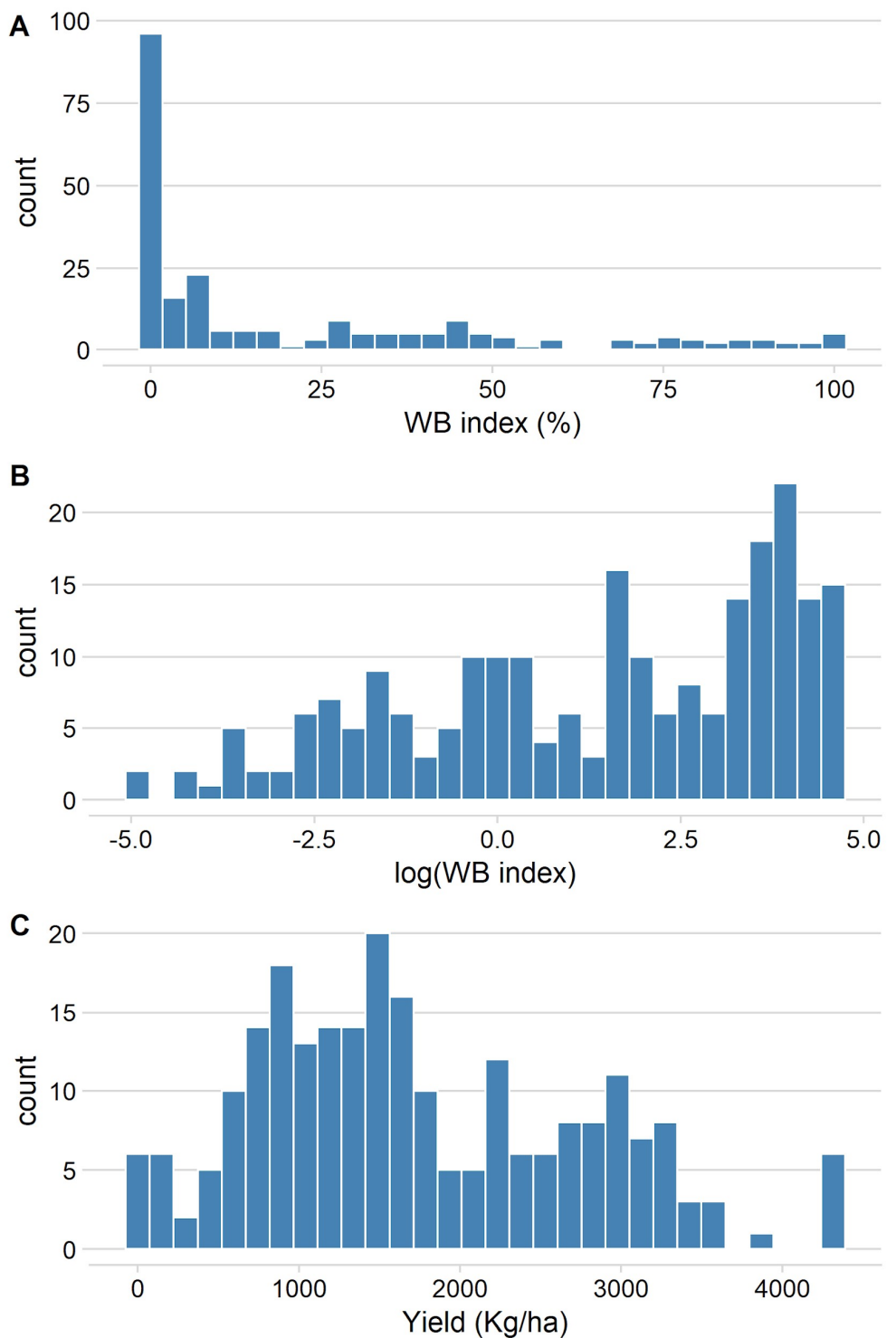

Fig. S1: Histograms for the distribution of Wheat blast index - WBI (A) and wheat grain yield (C) to check normality; B: log-transformed WBI data for normalizing the distribution and use in the meta-analysis models. 
Table S1. Designs (set of fungicide treatments by each trial) identified in 44 independent trials conducted from 2012 to 2020 in 11 municipalities across six Brazilian states (PR, SP, DF, MT, MS and MG).

\begin{tabular}{llcc}
\hline Design & \multicolumn{1}{c}{ Fungicides a.i. + untreated check $^{\text {a }}$} & WB index $^{\text {b }}$ & Yield $^{\mathrm{b}}$ \\
\hline 1 & $\begin{array}{l}\text { CHECK; AZOX+TEBU; MANC; PYRA+EPOX; TEBU; TFLX+PROT; } \\
\text { TFLX+TEBU }\end{array}$ & 4 & 4 \\
2 & CHECK; AZOX+TEBU; PYRA+EPOX; TEBU; TFLX+PROT; TFLX+TEBU & 5 & 5 \\
3 & CHECK; AZOX+TEBU; MANC; TEBU; TFLX+PROT; TFLX+TEBU & 8 & 9 \\
4 & CHECK; AZOX+TEBU; MANC; TFLX+PROT; TFLX+TEBU & 1 & 1 \\
5 & CHECK; MANC; PYRA+EPOX; TFLX+PROT; TFLX+TEBU & 10 & 13 \\
6 & CHECK; MANC; TEBU; TFLX+PROT; TFLX+TEBU & 1 & 1 \\
7 & CHECK; MANC; TFLX+PROT; TFLX+TEBU & 9 & 7 \\
8 & CHECK; TFLX+PROT; TFLX+TEBU & 1 & 2 \\
\hline
\end{tabular}

${ }^{\text {a }}$ See Table 1 for complete information about the treatments;

${ }^{\mathrm{b}}$ Number of trials that each design of treatments was identified for both WB index and yield. 
Table S2. Overall means and respective confidence intervals of log response ratio $\left(\underline{L}_{I N D}\right)$ and calculated percent control $(\underline{C})$ of Wheat Blast (WB) relative to untreated check provided by six fungicides evaluated during nine years (2012 to 2020) across 44 studies conducted in six Brazilian states (PR, SP, DF, MT, MS and MG).

\begin{tabular}{|c|c|c|c|c|c|c|c|c|c|}
\hline \multirow[b]{2}{*}{ Fungicide $^{\mathrm{a}}$} & \multirow[b]{2}{*}{$k^{\mathrm{b}}$} & \multicolumn{5}{|c|}{ Effect Size } & \multicolumn{3}{|c|}{ WB Control (\%) } \\
\hline & & $\underline{L}_{I N D}$ & $\mathrm{SE}(\underline{L})$ & $\mathrm{CI}_{\mathrm{L}}^{\mathrm{c}}$ & $\mathrm{CI}_{\mathrm{U}^{\mathrm{c}}}$ & $\mathrm{P}$ value & $\underline{C}$ & $\mathrm{Cl}_{\mathrm{L}}{ }^{\mathrm{c}}$ & $\mathrm{CI}_{U}^{\mathrm{c}}$ \\
\hline MANC & 33 & -0.8677 & 0.0904 & -1.0449 & -0.6905 & $<0.0001$ & 58.00 & 49.86 & 64.82 \\
\hline AZOX + TEBU & 18 & -0.7946 & 0.1144 & -1.0188 & -0.5704 & $<0.0001$ & 54.82 & 43.46 & 63.89 \\
\hline TFLX+PROT & 39 & -0.7745 & 0.0938 & -0.9583 & -0.5907 & $<0.0001$ & 53.90 & 44.60 & 61.64 \\
\hline TEBU & 18 & -0.7678 & 0.1035 & -0.9706 & -0.5650 & $<0.0001$ & 53.59 & 43.16 & 62.11 \\
\hline TFLX+TEBU & 39 & -0.7395 & 0.0854 & -0.9068 & -0.5722 & $<0.0001$ & 52.26 & 43.56 & 59.61 \\
\hline PYRA+EPOX & 19 & -0.5669 & 0.0939 & -0.7509 & -0.3829 & $<0.0001$ & 43.27 & 31.81 & 52.80 \\
\hline
\end{tabular}

a See Table 1 for complete information of the evaluated fungicides;

${ }^{\mathrm{b}}$ number of trials that each fungicide was evaluated;

${ }^{c}$ upper $(\mathrm{Clu})$ and lower $\left(\mathrm{CI}_{\mathrm{L}}\right)$ limits of the $95 \%$ confidence interval around $\underline{L}_{I N D}$ and $\underline{C}$. 
Table S3. Overall means and respective confidence intervals of unstandardized difference in wheat grain yield $(\underline{D})$ between fungicide-treated and untreated plots, and percent yield increase $(\underline{Y})$ for six selected fungicide treatments evaluated during nine years (2012 to 2020) across 44 studies conducted in six Brazilian states (PR, SP, DF, MT, MS and MG).

\begin{tabular}{|c|c|c|c|c|c|c|c|c|c|}
\hline \multirow[b]{2}{*}{ Fungicide $^{\mathrm{a}}$} & \multirow[b]{2}{*}{$k^{\mathrm{b}}$} & \multicolumn{5}{|c|}{ Effect size } & \multicolumn{3}{|c|}{ Yield Return (\%) } \\
\hline & & $\underline{D}$ & $\mathrm{SE}(\underline{D})$ & $\mathrm{CI}_{\mathrm{L}}^{\mathrm{c}}$ & $\mathrm{CI}_{U^{\mathrm{c}}}$ & $P$ value & $\underline{Y}$ & $\mathrm{CI}_{\mathrm{L}}^{\mathrm{c}}$ & $\mathrm{CI}_{U^{c}}^{\mathrm{c}}$ \\
\hline MANC & 35 & 420.10 & 53.30 & 315.62 & 524.57 & $<0.0001$ & 47.55 & 32.25 & 64.62 \\
\hline TEBU & 19 & 319.46 & 49.91 & 221.63 & 417.29 & $<0.0001$ & 38.68 & 26.54 & 51.98 \\
\hline AZOX + TEBU & 19 & 301.48 & 43.75 & 215.73 & 387.24 & $<0.0001$ & 37.01 & 23.07 & 52.51 \\
\hline TFLX+PROT & 42 & 299.73 & 39.69 & 221.92 & 377.53 & $<0.0001$ & 32.42 & 21.84 & 43.93 \\
\hline TFLX+TEBU & 42 & 245.34 & 36.98 & 172.85 & 317.83 & $<0.0001$ & 29.08 & 19.13 & 39.86 \\
\hline PYRA+EPOX & 22 & 181.15 & 33.85 & 114.79 & 247.50 & $<0.0001$ & 23.76 & 14.62 & 33.64 \\
\hline
\end{tabular}

${ }^{a}$ See Table 1 for complete information on the fungicides;

${ }^{\mathrm{b}}$ number of trials that each fungicide was evaluated;

${ }^{\mathrm{c}}$ upper $(\mathrm{CIU})$ and lower $\left(\mathrm{CI}_{\mathrm{L}}\right)$ limits of the $95 \%$ confidence interval around $\underline{D}$ and $\underline{Y}$. 